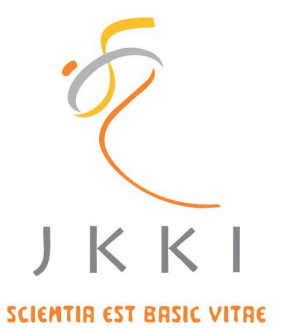

Jurnal Kedokteran dan Kesehatan Indonesia

Indonesian Journal of Medicine and Health

Journal homepage: https://journal.uii.ac.id/JKKI

\title{
Relationship between knowledge of acute respiratory tract infection and use of face masks in motorcyle online drivers
}

Ahmad Saepudin ${ }^{1}$, Eveline Margo*2

${ }^{1}$ Faculty of medicine, Universitas Trisakti, Jakarta, Indonesia

${ }^{2}$ Department of Physiology, Faculty of Medicine, Universitas Trisakti, Jakarta, Indonesia

Original Article

\begin{tabular}{l}
\hline \\
\hline ART ICLE I N F O \\
\hline Keywords: \\
ARI knowledge, \\
use of masks, \\
online motorcycle drivers \\
*Corresponding author: \\
eveline_margo@yahoo.com \\
\hline DOI: 10.20885/JKKI.Vol12.Iss1.art3 \\
\hline History: \\
Received: September 19, 2019 \\
Accepted: November 11, 2020 \\
Online: April 30, 2021 \\
\hline Copyright @2021 Authors. \\
This is an open access article \\
distributed under the terms \\
of the Creative Commons At- \\
tribution-NonCommercial 4.0 \\
International Licence (http:// \\
creativecommons.org/licences/ \\
by-nc/4.0/).
\end{tabular}

\section{ABSTRACT}

Background: Data in 2013 states that the prevalence of acute respiratory infections (ARI) is $25 \%$. One of the factors that cause ISPA is air pollution. This factor is one of the risk factors for motorcycle taxi drivers who are always exposed to air pollution. Knowledge of ARI that is sufficient to influence the use of masks can help prevent ARI from occurring.

Objective: This study aims to determine the relationship between knowledge of ARI and the behaviour of using masks among online motorcycle drivers.

Methods: This study was an analytical observational with a crosssectional design attended by 139 online motor cycle drivers around Grogol, Petamburan, West Jakarta, from July to December 2017. Data collection was done by filling out a questionnaire that includes demographic data, the use of masks, and knowledge of ARI. Data analysis used Fisher's test with significance level $\mathrm{p}<0,05$.

Results: A total of 139 respondents were collected, consisting of 131 $(94.2 \%)$ men and 8 (5.8\%) women. The average age of $\geq 30$ years old is 77 (55.4\%) people. Most respondents' education level was SMA/SMK/SLTA as many as 111 (79.9\%) people. From the results of Fisher's test, it was found that the probability value $\mathrm{p}=0.362$ was greater than the significance value (0.05).

Conclusion: There is no significant relationship between the level of knowledge about ARI and the use of masks among online motorcycle drivers.

Latar Belakang: Data Riskesdas 2013 menyatakan bahwa prevalensi infeksi saluran pernapasan akut (ISPA) sebesar 25\%. Salah satu faktor yang menyebabkan terjadinya ISPA adalah polusi udara. Faktor tersebut menjadi salah satu faktor risiko bagi pengendara ojek yang selalu terpapar polusi udara. Pengetahuan tentang ISPA yang cukup berpengaruh terhadap penggunaan masker dapat membantu mencegah terjadinya ISPA.

Tujuan: Penelitian ini bertujuan untuk mengetahui hubungan antara pengetahuan tentang ISPA dengan perilaku penggunaan masker pada pengendara ojek online.

Metode: Penelitian ini merupakan studi observional analitik dengan desain Cross-sectional yang diikuti oleh 139 pengendara ojek di sekitar Grogol, Petamburan, Jakarta Barat selama bulan Juli hingga Desember 2017. Pengumpulan data dengan melakukan pengisian kuesioner yang meliputi data demografi, penggunaan masker, dan pengetahuan tentang ISPA. Analisis data dengan menggunakan uji Fisher's dengan tingkat kemaknaan $p<0,05$.

Hasil: Sebanyak 139 responden yang berhasil dikumpulkan terdiri dari 131 (94,2\%) laki-laki dan 8 (5,8\%) 
perempuan. Rata-rata berusia $\geq 30$ tahun sebanyak 77 (55,4\%) orang. Tingkat pendidikan responden paling banyak adalah SMA/SMK/SLTA sebanyak 111 (79.9\%) orang. Dari hasil uji Fisher's didapatkan nilai probabilitas yaitu $p=0,362$ lebih besar dari nilai kemaknaan $(0,05)$.

Kesimpulan: Tidak terdapat hubungan bermakna antara tingkat pengetahuan tentang ISPA dan penggunaan masker pada pengendara ojek online.

\section{INTRODUCTION}

The transportation sector plays a considerable role compared to other sectors in terms of air pollution. Some related factors are the high number of old vehicles with poor maintenance, inadequate infrastructure, and low fuel quality. ${ }^{1}$ In major cities in Indonesia, exhaust gas from motorized vehicles is one of the largest air pollution sources compared to exhaust gas from industrial chimneys and other sources of combustion. ${ }^{2}$

In general, two-wheeled motorised vehicles or motorbikes are still one of the main transportation choices for the community for the mode of transportation. Motorbikes are commonly used as private vehicles or public transportation such as motorbikes taxis, often called Ojek. Currently, Ojek is growing rapidly in the capital city because it can travel a certain distance quickly compared to other transportation, which has to deal with road congestion in the city of Jakarta. ${ }^{3}$ An online motorcycle taxi business, namely Gojek, which is already operating in Jakarta, Bali, Bandung, and Surabaya with 10,000 riders, has taken over the transportation system in major cities. ${ }^{4}$ Data for 2015 from the Central Statistics Agency of DKI Jakarta Province states that motorcycle ownership has grown from year to year. Motorcycle ownership in Jakarta, which reached 11,949,280 in 2013, increased in 2014 to $13,084,374 .^{5}$

The 2013 Riskesdas data states that the prevalence of Acute Respiratory Infection (ARI) based on the diagnosis of health professionals and the population's complaints is $25.0 \%$. The five provinces with the highest number of ARI sufferers were East Nusa Tenggara (41.7\%),
Papua (31.1\%), Aceh (30.0\%), West Nusa Tenggara (28.3\%), and East Java (28,3\%), while for DKI Jakarta (25.2\%) and Banten (25.8\%). The characteristics of the population who suffer from ARI do not differ between men (25.1\%) and women (24.9\%). ${ }^{4}$ A study from the Ministry of Health in 2010 showed that ARI disease was the number one disease experienced by districts/cities in 22 provinces in Indonesia which was caused by the low quality of air inside the house/building and outside the house, both physically, chemically, and biologically. ${ }^{6}$

It is known that motor vehicle exhaust gases are more easily exposed to the public because of motorised vehicle engines' imperfect combustion process. People who often do activities around the highway, such as motorists, pedestrians, and traffic police, are often exposed to pollutants from engine combustion which has a high enough fuel content. ${ }^{6}$ Pollutants released by motorised vehicles include carbon monoxide. (CO), nitrogen oxides (NOx), hydrocarbons $(\mathrm{HC})$, sulfur dioxide $\left(\mathrm{SO}_{2}\right)$, lead $(\mathrm{Pb})$, and carbon dioxide $\left(\mathrm{CO}_{2}\right)$. Of these several types of pollutants, carbon monoxide ( $\mathrm{CO}$ ) is one of the most pollutants produced by motorised vehicles. If these pollutants' levels indicate an addition to the ambient air quality standard, it will cause several health problems. Complaints that quite often occur in the eyes (eyes feel stinging and watery), inflammation of the respiratory tract, pulmonary puffiness, chronic bronchitis, emphysema, or other pulmonary disorders. ${ }^{7-9}$ Air pollution is a condition in which air quality becomes damaged and contaminated by substances that endanger the human body's health and decrease environmental quality. It is caused by several things, including transportation, household activities, and industrial processing which originates from the use of fuel used in industrial processes. Pollutants will enter the body through the respiratory system, from the lungs, and are absorbed by the respiratory and circulatory system. ${ }^{9}$

Acute respiratory tract infection is an infectious disease that attacks the respiratory 
tract from the nose to the lower alveoli, including adnexal tissue such as the sinuses, middle ear cavity, and pleura. The process of infection takes up to 14 days. ${ }^{10} \mathrm{ARI}$ is a common condition that affects most people at any given time, some of which are acute, with symptoms that last a long time or happen repeatedly. Symptoms that appear in ARI include nasal congestion, sore throat, and cough due to exposure to the inhaled pathogenic germs. ${ }^{11}$ Hence, prevention efforts should be the priority to avoid the morbidity of the disease. One way that can be done by using Personal Protective Equipment (PPE). PPE is a set of safety tools used by workers to protect all or part of their body from possible exposure to potential hazards of the work environment to work-related accidents and diseases. ${ }^{12}$ The most common PPE used on the road is a mask, a respiratory protective device covering the mouth and nose. Nowadays, masks are easy to find, and many road users have protected themselves against the harmful effects of air pollution. ${ }^{13}$

A study by Ludyaningrum found a significant relationship between the use of masks on motorcyclists and the frequency of ARI symptoms. ${ }^{13,14}$ On the contrary, Noer found no relationship between symptoms of ARI and the habit of wearing PPE among phosphoric acid factory workers. ${ }^{15}$ Based on the background above, researchers are interested in analyzing the relationship between ARI knowledge and the use of masks in online motorcycle taxi drivers.

\section{METHODS}

This study was conducted with an observational analytic design with a crosssectional method to analyse the relationship between ARI knowledgeand the use of masks among online motorcycle taxi drivers from July to December 2017. The population in this study were all online motorcycle taxi riders operating around the Grogol Petamburan area. West Jakarta, selected by Consecutive nonprobability sampling, totalling 139 respondents. The inclusion criteria in this study were motorcycle taxi drivers who were still actively operating, physically and mentally healthy, and willing to sign an informed consent. Collecting data by filling out a questionnaire then analysed the data using Fisher's test with a significance level of $p<0.05$. Univariate analysis to describe respondents' characteristicsin the form of gender, age, education level, use of masks, and level of knowledge about ARI. Bivariate analysis of the relationship between ARI knowledgeand the use of masks in motorcycle taxi riders using Fisher's test with a significance level of 95\% using the SPSS program version 22. This study has passed the ethical review from the Faculty of Medicine, Trisakti University with No. 09 / KER-FK / VII / 2017.

\section{RESULTS}

A total of 139 respondents were collected, consisting of 131 men (94.2\%) and 8 women $(5.8 \%)$. The average age of $\geq 30$ years was 77 people (55.4\%). The education level of the most respondents was senior high school as many as 111 people (79.9\%), followed by junior high school as 11 people (7.9\%), elementary as many as 9 people (6.5\%), University graduates as many as 5 people $(3.6 \%)$ and the last Diploma is 3 people $(2.2 \%)$. The majority of respondents have low knowledge of ARI, consisting of 126 people (90.6\%) meanwhile, those with high knowledge were 13 people $(9.4 \%)$. In terms of using masks, more respondents were using masks, with 125 people (89.9\%) compared to 14 people (10.1\%) who did not use them (Table 1).

To find out whether there is a relationship between the level of knowledge about ARI and the use of masks in motorcycle taxi drivers, bivariate analysis was carried out with Fisher's test, and a description of 13 respondents who had high knowledge of ARI and all of them used masks (100\%), and those who had low ARI knowledge as many as 112 (88.9\%) people and who did not use masks as many as $14(11.1 \%)$ people. The level of knowledge about ISPA with the use of masks by motorcycle taxi drivers obtained a value of $p=0.362$, which means that it is greater than the value of $\alpha=0.05$, it can be concluded 
that there is no significant relationship between the level of knowledge about ISPA and the use of masks on motorcycle taxi drivers.

Table 1. Distribution of gender, age, level of education, use of masks, ARI knowledge.

\begin{tabular}{lcc}
\hline $\begin{array}{c}\text { Characteristics } \\
\text { (n=139) }\end{array}$ & $\begin{array}{c}\text { Number } \\
\text { (n) }\end{array}$ & $\begin{array}{c}\text { Percentage } \\
\text { (\%) }\end{array}$ \\
\hline Gender & 131 & 94.2 \\
Male & 8 & 5.8 \\
Female & & \\
Age & 62 & 44.6 \\
$<30$ year & 77 & 55.4 \\
$\geq 30$ year & & \\
Education level & 9 & 6.5 \\
Elementary & 11 & 7.9 \\
Junior high school & 111 & 79.9 \\
Senior high school & 3 & 2.2 \\
Diploma & 5 & 3.6 \\
University graduates & & \\
ARI knowledge & 13 & 9.4 \\
High & 126 & 90.6 \\
Low & & \\
Mask Use & 125 & 89.9 \\
Yes & 14 & 10.1 \\
No & & \\
\hline
\end{tabular}

\section{DISCUSSION}

This study shows no significant relationship between ARI knowledge and the use of masks on motorcycle taxi drivers with a value of $p=0.362$. It was regardless that majority of respondents were senior high school graduates (79.9\%). This result is in line with the research conducted by Noer, who found that there was no relationship between ARI symptoms and the habit of wearing PPE on phosphoric acid factory workers. ${ }^{15}$ However, a study conducted by Ludyaningrum showed a significant relationship between the application of masks among motorcyclists and the frequency of ARI symptoms. Similarly, Purwani et al. and Nurrizqi et al. also stated a relationship with the level of closeness between the habit of using PPE (masks) and complaints of respiratory tract disorders. It is stated that broader knowledge resulting in improved behaviour. ${ }^{13,14,16}$ However, research conducted by Septi et al. on postal couriers at PT. Posindo's Erlangga Semarang branch stated that most (64.8\%) respondents did not wear masks while driving. This is not related to their knowledge that mask application was useful for safety and health which served to protect motorists from air pollution to avoid respiratory problems such as ISPA.

In this study, the results were not significant since using a mask is an operational standard that obligates online motorcycle taxi riders and makes them feel more comfortable using a mask when riding a motorbike. Although most (89.9\%) used masks, 90.6\% had a low level of ARI knowledge. 
One of the influencing factors to the knowledge about ARI is a personal education level. The higher education level is related to the greater understanding, which influences someone in making the right attitude. Education will affect all aspects of human life both in terms of thoughts, feelings, and attitudes. Besides, age may also influence the intensity of knowledge. Younger people tend to have more accurate memory with higher creativity in finding and recognising the previously unknown topics compared to older people. ${ }^{18}$ However, several studies stated that many other factors influence a person's decision to apply a mask, and convenience has a bigger role. Many respondents do not feel comfortable when using a mask while driving and also feel short of breath when using it; therefore, they decided no to wear one. ${ }^{13,19,20}$

This study was limited by only a single location used with a relatively constrained time. Besides, the field report said that it might be biased by the fact that using a mask is mandatory operational standards required by the company to be obeyed by the drivers.

\section{CONCLUSION}

There was no significant relationship between the level of knowledge about ARI, age, and the use of masks among online motorcycle taxi drivers. For further research, it is expected to connect the level of knowledge with complaints of ARI and the distance travelled when riding a motorcycle, and research is carried out in more than one area to improve the accuracy of the research carried out.

\section{CONFLICT OF INTEREST}

The author states there is no conflict of interest.

\section{ACKNOWLEDGEMENT}

The author would like to thank all research subjects who have been willing to participate in this research.

\section{REFERENCES}

1. Ismiyati, Marlita D, Saidah D. Pencemaran udara akibat emisi gas buang kendaraan bermotor. Jurnal Manejemen Transportasi dan Logistik. 2014;1(3):241-7.

2. Djafri D. Survival analysis gangguan pernapasan dengan tingkat pajanan pencemaran udara di DKI Jakarta (Studi Cohort Pada Murid Sekolah Dasar). Jurnal Kesehatan Masyarakat Andalas. 2007;2(1):124-32.

3. Pratama A, Prasamtiwi GN, Sartika S. Kebersyukuran dan kepuasan hidup pada tukang ojek. Jurnal Psikologi 2015;8(1):41-42.

4. Rifaldi R, Kadunci K, Sulistyowati S. Pengaruh kualitas pelayanan transportasi online gojek terhadap kepuasan pelanggan pada mahasiswa/i administrasi niaga politeknik negri Jakarta. Epigram 2016;13(2):121-8.

5. Amajida FD. Kreativitas digital dalam masyarakat risiko perkotaan: studi tentang ojek online "go-jek" di Jakarta. Informasi 2016;46(1):115-28.

6. Riset Kesehatan Dasar 2013. Jakarta: Badan Penelitian dan Pengembangan Kesehatan; 2013.

7. Suharti N, Munir E, Suryanto D, Agusnar H. Hubungan antara populasi mikroorganisme udara dengan kejadian ISPA di sekitar tempat pembuangan akhir sampah terjun Medan. Jurnal Pendidikan Kimia 2014;6(1):1120.

8. Muziansyah D, Sulistyorini R, Sebayang S. Model emisi gas buangan kendaraan bermotor akibat aktivitas transportasi (Studi kasus: Terminal Pasar Bawah Ramayana Koita Bandar Lampung). JRSDD 2015;3(1):57-70.

9. Sengkey LS, Jansen F, Wallah S. Tingkat pencemaran udara CO akibat lalu lintas dengan model prediksi polusi udara skala mikro. Jurnal Ilmiah Media Engineering 2011;1(2):119-20.

10. Kementerian Kesehatan RI. Pedoman pengendalian infeksi saluran pernapasan akut. Jakarta: Direktorat Jenderal Pengendalian Penyakit dan Penyehatan Lingkungan, 2012.

11. Smeltzer SC, Bare BG. Textbook of medical surgical nursing Vol.2. Philadelphia: Linppincott William \& Wilkins, 2008.

12. Tarwaka. Keselamatan dan kesehatan ker- 
ja manajemen dan implementasi kesehatan dan keselamatan kerja di tempat kerja. Surakarta: Harapan Press,2008.

13. Ludyaningrum RM. Perilaku berkendara dan jarak tempuh dengan kejadian ISPA pada mahasiswa Universitas Airlangga Surabaya. Jurnal Berkala Epidemiologi 2016; 4(3): 371-83.

14. Purwani K, Rudira WA. Hubungan penggunaan masker dengan gangguan kesehatan respirasi pada pengendara motor mahasiswa Universitas Islam As-Syafi'iyah. Jurnal Afiat Kesehatan dan Anak. 2016; 2(2): 187-96.

15. Noer RH, Martiana T. Hubungan antara karakteristik dan perilaku pekerja dengan gejala ISPA di pabrik asam fosfat Departemen Produksi III PT. Petrokimia Gresik. The Indonesian Journal of Occupational Safety and Health. 2013;2(2):130-6.

16. Nurrizqi MA, Wardani HE, Gayatri RW. Hubungan riwayat penyakit, APD, pendidikan, dan umur dengan keluhan ISPA pada pekerja di kawasan industri mebel Kelurahan Bukir Kecamatan Gadingrejo Kota Pasuruan. Sport Science and Health 2019; 1(1): 39-50.

17. Wulandari S, Jayanti S, Widjasena B. Faktor-faktor yang berhubungan dengan perilaku berkendara aman (safety riding) pada kurir pos sepeda motor di PT. Pos Indonesia cabang Erlangga Semarang. Jurnal Kesehatan Masyarakat. 2017; 5(5): 34655.

18. Maramis PA, Ismanto AY, Babakal A. Hubungan tingat pendidikan dan pengetahuan ibu tentang ISPA dengan kemampuan ibu merawat balita ISPA pada balita di puskesmas Bahu kota Manado. Jurnal Keperawatan. 2013;1(1):1-8.

19. Ningsih JA, Setiyabudi R. Faktor ISPA pada pekerja penggilingan padi. Jurnal Kesehatan. 2020; 11(2): 105-10.

20. Hafsari D, Ramadhian MR, Saftarina F. Debu batu bara dan kejadian infeksi saluran pernafasan akut pada pekerja pertambangan batu bara. Majority. 2016; 4(9):35-41. 